\title{
Factors Affecting Employee Satisfaction among Non-teaching Staff in Higher Educational Institutions in Malaysia
}

\author{
Sarah Yuliarini, Nik Kamariah Nik Mat", Pranav Kumar \\ Othman Yeop Abdullah Graduate School of Business, Universiti Utara Malaysia, Sintok, 06010, Malaysia
}

\begin{abstract}
The purpose of this study is to examine the factors which influence employee satisfaction among the senior non-teaching staff members in higher educational institutions in Malaysia. Employee satisfaction leads to ensuring that a higher productivity is derived from all employees within an organization. The four variables viz. management knowledge, leadership, training and employee satisfaction were measured using a 5-point interval scale. Using Structured Equation Modeling (SEM) technique, it was found that leadership has a significant impact on employee satisfaction whereas management knowledge and training do not significantly influence employee satisfaction.
\end{abstract}

Keywords Employee Satisfaction, Non-Teaching Staff, Higher Education Institutions, Structure Equation Modeling (SEM), Leadership, Training, Management Knowledge

\section{Introduction}

In everyday life, students always interact with non-teaching personnel for academic purposes. It starts from the application, registration, examination issues, and the lecturing schedule in addition to many others. Even though website and other helpful sources give the information according to their needs, it could be argued that students find difficulty when dealing with the non-teaching personnel as compared to the teaching professionals in higher educational institutions. It can adversely affect the image of an institution. That is why employee satisfaction among the non-teaching personnel is amply indispensable as it further leads to the quality of treatment they offer to the students.

Employee satisfaction is considered in empirical studies either as an overall feeling about the job, or as a related set of attitudes about various aspects of the job[1]. Locke[2] defined employee satisfaction as "...a pleasurable or positive emotional state resulting from the appraisal of one's job or job experience".

\subsection{Research Problem}

Employee satisfaction is often linked to the quantity. 'Pay for performance' is most likely the criterion of an or ganization to gage its employee performance. Smith, Kendall and Hulin[3]; Spector[1] stated that employee satisfaction is the

* Corresponding author:

drnikuum@gmail.com (Nik Kamariah Nik Mat)

Published online at http://journal.sapub.org/economics

Copyright (C) 2012 Scientific \& Academic Publishing. All Rights Reserved positive affective response people have to their jobs and employment. Employee satisfaction is important, as it is associated with better job performance[4], lower absenteeism[5], higher organizational citizenship, greater organizational commitment[6], lower intention to leave[7], lower turnover[8],[9], and better safety[9]. It is also an important component of overall well-being. This research is an attempt to articulate the factors which have supreme influence on employee satisfaction among the senior non-teaching staff in Universiti Utara Malaysia.

\subsection{Research Objective}

The objectives of this research are:

1. To determine the direction and extent of relationship between leadership and employee satisfaction

2. To ascertain the direction and extent of relationship between training and employee satisfaction

3. To determine the direction and extent of relationship between management knowledge and employee satisfaction

\section{Literature Review}

\subsection{Employee Training and Employee Satisfaction}

The research indicated that training has positive impact on employee's productivity, which results in higher levels of employee satisfaction[10]. Numerous studies observe that workers who receive training report higher levels of job satisfaction. Marie[11] stated the development of competencies through various training programmes has a positive impact on employee satisfaction. In particular, employee 
training increases an employee's ability to perform tasks[10]. The different research studies also argued that a lack of training has been attributed to shorter employment tenure, frustration and job dissatisfaction[12]. Therefore, it is important to make clear the casual linkage between employee training and satisfaction, whether the employee training will increase employee satisfaction or not.

\subsection{Leadership and Employee Satisfaction}

The relationship between leadership behavior and job satisfaction has also received a great deal of attention in past research. Leadership refers to the process of influencing the team to accomplish the goals[13]. Leaders are key success factors of an organization[14]. Skillful leaders recognize and use the interpersonal relationships in the teams and strengthen the members' loyalty and morale. Effective leaders must learn skills such as patiently sharing information, trusting others and recognizing the timing of interventions[15]. In recent years, numerous scholars have tried to discuss leadership from new perspectives including employee satisfaction.

\subsection{Management Knowledge and Employee Satisfaction}

One of the major factors that affects the commitment, work effort and employee satisfaction of staff is the way they are organized and also how they relate to the management. Employees need to possess adequate management knowledge. In the extant work, May, Korczynski and Frenkel[16] presented the market model of knowledge work organization. Management often adopts new practices and measures that bring pressures onto the firm to manage employment relations and work motivation. The psychological contract that used to bond employees and organisation together is in decline.

\subsection{Hypothesis}

Based on the above, we came up with following hypothesis for this study:

H1: There exists direct relationship between training and employee satisfaction.

H2: There exists direct relationship between leadership and employee satisfaction.

H3: There exists direct relationship between management knowledge and employee satisfaction.

\section{Data and Method}

\subsection{Research Framework}

Based on the literature and researcher's focus on the satisfaction of senior non-teaching staff, this study explicitly identified employee satisfaction as the endogenous variable. And the three exogenous variables identified for the study were training, leadership and management knowledge (Figure 1).

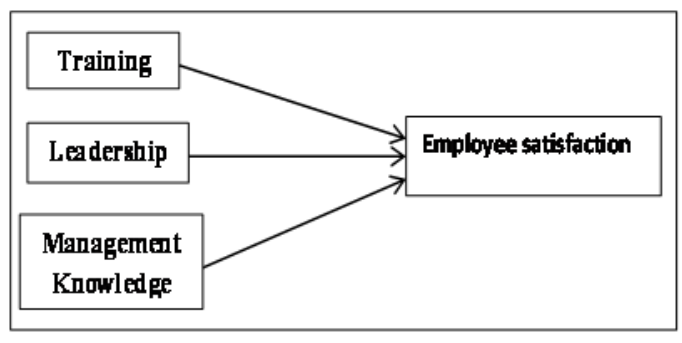

Figure 1.

\subsection{Sampling}

A discussion was carried out with the UUM administration and it was jointly identified that there are around 400 staff eligible for this survey according to the objectives and seniority factors identified as per this study. Technical, support, marketing and other staff were given more importance in the sampling process for this study. From there, we finally circulated questionnaire to 150 staff and we received a response rate of $66.6 \%$.

\subsection{Questionnaire Design}

For this study, a standardized questionnaire was designed in accordance with the three hypotheses wherein the three independent variables viz. Management knowledge, leadership and training consisted of 3, 6 and 7 items respectively. On the other hand, employee satisfaction, the dependent variable consisted of 6 items. A Likert's scale of 5 options was used for each of the items. After conducting the face validity with 10 experts and incorporating their suggestions, the study also involved a piloting exercise with 30 samples to ensure that the instruments are appropriately usable and conforms to the statistical and structured equation modeling (SEM) requirements in terms of Chronbach alpha, composite reliability, etc.

\subsection{Data Analysis}

This study used structured equation modeling (SEM) technique and relied on the uses of AMOS 20 and SPSS 19 for data analysis. Exploratory factor analysis (EFA) and confirmatory factor analysis (CFA) were conducted for all variables individually to ensure that the items are free from high correlational relationships with an ultimate aim to achieve the model fit. It was carried out after consistent amendments in the data set according to needs identified by normality and modification indices (MI) in order to achieve adequate goodness of fit. Thereafter, the hypothesized model was developed which initially showed Heywood cases and thus it had to undergo some modifications according to the abnormalities highlighted through several indices in the AMOS output.

\section{Finding}

Upon completion of the above, finally the revised model was achieved meeting all requirements and possessed ade- 
quate goodness of fit with values for ratio as 1.588 , P-Value as .074, GFI as .953 and RMSEA as .077 (Table 1 in appendix). The findings showed that leadership has a significant impact on employee satisfaction whereas management knowledge and training do not significantly influence employee satisfaction.

\subsection{Hypothesis Results}

It was found that only hypothesis 2 (H2) is supported ( $\beta=.831, \mathrm{CR}=3.66, \mathrm{P}=.001$ ). It shows that there is a direct and significant relationship between leadership and employee satisfaction. Hypothesis 1 (H1) was not supported ( $\beta=-0.598, C R=-1.872, P=.061$ ) which shows that there is no direct impact of training on employee satisfaction. Hypothesis 3(H3) was also not supported by the findings ( $\beta=.143, C R=.766, P=.444$ ) which exhibits that management knowledge and employee satisfaction possess no significant relationship (Table 2 in appendix). Additionally, with a SMC of .579 for ES, the revised model explains $57.9 \%$ variance in employee satisfaction.

\section{Discussion}

This study supports that there is a significant relationship between leadership and employee satisfaction. It is in line with the new studies of leadership theory which have particularly stressed on the influences of demands between leaders and subordinates, the interaction of personality traits and situational factors on leadership[17]. Leaders must select a proper leadership style according to their subordinates' different demands for supervision, in order to enhance employee satisfaction and fulfill expected goals. Leaders can develop their subordinates' potential and enhance their confidence and satisfaction by changing their values and beliefs in order to increase their organizational commitment, intention and motivation to create exceptional outcomes.

Training and management knowledge have been found to have insignificant relationship in this study which is in contradiction with many studies done previously. It can be attributed to the fact that in higher education institutions, senior employees already possess reasonably appropriate amount of training and management knowledge and probably therefore, these factors do not play a major role in enhancing their satisfaction.

\section{Conclusions Future Research}

This study took into account three exogenous variables and one endogenous variable. During the study, the researchers observed that long term plans and fair growth options may have some moderation effect on the satisfaction of these employees. Future research can be directed towards studying their moderation effects. Also, rise in monetary benefits at regular intervals can be studied as an exogenous variable and thus its relationship with employee satisfaction can be further studied. We also suggest some qualitative study in order to throw further light on why training and management knowledge have less significant impact on employee satisfaction in context of senior non-teaching staff in higher educational institutions.

\section{REFERENCES}

[1] Spector, P.E., Job Satisfaction: Application, Assessment, Cause, and Consequences, Sage, Thousand Oaks, CA (1997).

[2] Locke, E., 'The nature and causes of job satisfaction', in Dunnette, M. (Ed.), Handbook of Industrial and Organiza-tional Psychology, Rand McNally, Chicago (1976), IL, pp. 1297-1349.

[3] Smith, P.C., Kendall, L.M., and Hulin, C.L., The measure-ment of satisfaction in work and retirement. Chicago, IL: Rand McNally. (1969).

[4] Judge, T.A., Thoresen, C.J., Bono, J.E., and Paton, G.K. (2001). The job satisfaction performance relationship: A qu-alitative and quantitative review. Psychological Bulletin, 127, 376-407.

[5] Saari, L.M., and Judge, T.A.(2004). Employee Attitudes and Job Satisfaction. Human Resource Management 43(4), pp. 395-407.

[6] Mayer, J.P., Stanley, D.J., Herscovitch, L., Topolnitzky, L.(2002). Affective continuance, and normative commitment to the organization: A meta- analysis of antecedents, correlates, consequences. Journal of Vocational Behaviour. 61, pp.20-52.

[7] Wilson, B., Laschinger, H.K.S. (1994). Staff nurse perception of job empowerment and organizational commitment. J. Nurs. Admin., 24(4): 39-47.

[8] Griffeth, R.W., Hom, P.W., and Gaertner, S. (2000). A me-ta-analysis of antecedents and correlates of employee turnover: Update, moderator tests, and research implication for the next millennium. Journal of Management., 26(3), pp.463-488.

[9] Harter, J.K., Schmidt, F.L., and Hayes, T.L.(2002). 'Busi-ness-Unit-Level relationship between employee satisfaction, employee engagement, and business outcomes: A me-ta-analysis. Journal of Applied Psychology 7(2), pp.268-279

[10] Choo, S., and Bowley, C. (2007). Using training and devel-opment to affect job satisfaction within franchising. Journal of Small Business and Enterprise Development, 14(2), 339-352.

[11] Marie, W. (1995). The effects of self-regulatory coping orientation on new comer adjustment and job survival. Per-sonnel Psychology, 48(3), pp. 633-650.

[12] Pugh, S.(1984). Management training versus training in library management. Information and Library Manager, 3(2), 35-37.

[13] Robbins, S., Coulter, M. Management (8th ed.). NJ: Pren-tice-Hall (2005). 
[14] Bass, B.M., Leadership and Performance Beyond Expecta-tions, NY: Harper and Row. (1985)

[15] Steckler, N., and Fondas, N.(1995). Building team leader effectiveness: A diagnostic tool. Organizational. Dynamic, 23(3), pp. 20-35.

[16] May, T.Y.M., Korzinky, M., Frenkel, S.J. (2002). Organi- za-tional And Occupational commitment: Knowledge Workers In Large Corporations. Journal of Management Studies 39:6. September, 775-781.

[17] Bargal, D., and Schmid, H. Recent themes in theory and research on leadership and their implications for management of the human services. Admin. Social work (1989), 13(1): $37-55$. 